\title{
Peningkatan Pemahaman Manajemen Waktu Melalui Bimbingan Kelompok Dengan Teknik Problem Solving pada Siswa
}

\author{
Diana Dwi Nurhidayati \\ SMP N 10 Mesuji Makmur \\ Labuhan Jaya, Mesuji Makmur, Ogan Komering Ilir, Sumatra Selatan, Indonesia \\ Email: dianadwinurhidayati@gmail.com
}

\begin{abstract}
The purpose of this study is to determine the increase of time management understanding through group guidance with problem solving techniques. This research is a classroom action research with cross sectional type. The subjects of research were ten students of class VII A SMP Muhammadiyah 4 Yogyakarta taken by purposive sampling technique. Data collection instrument used was in the form of a questionnaire of time management understanding. Data analysis technique to test the effectiveness of group guidance was problem solving technique which is to improve the understanding of time management of SMP students using the Wilcoxon test. The results of data analysis shows a mean of time management understanding before the action of problem solving techniques was 55.30 and the average after problem solving techniques given was 78.60. Wilcoxon test results shows $p=0.005$ so that we can conclude that there is an increase of time management understanding of SMP students after using group guidance with problem solving techniques. The results of this study can be useful for guidance and counseling teachers as a consideration material in improving the understanding of students' time management through group guidance services using problem solving techniques.
\end{abstract}

Keywords: group guidance, problem solving, time management

Tujuan penelitian ini untuk mengetahui peningkatan pemahaman manajemen waktu melalui bimbingan kelompok dengan teknik problem solving. Penelitian ini merupakan penelitian tindakan kelas dengan jenis cross sectional. Subjek penelitian sepuluh siswa kelas VII A SMP Muhammadiyah 4 Yogyakarta yang diambil dengan teknik purposive sampling. Instrumen pengumpulan data yang digunakan berupa angket pemahaman manajemen waktu. Teknik analisis data untuk menguji keefektifan bimbingan kelompok dengan teknik problem solving untuk meningkatkan pemahaman manajemen waktu siswa SMP menggunakan uji wilcoxon. Hasil analisis data menunjukkan pemahaman manajemen waktu sebelum diberi tindakan teknik problem solving dengan rerata sebesar 55,30 dan setelah diberi tindakan teknik problem solving dengan rerata sebesar 78,60. Hasil uji wilcoxon menunjukkan $\mathrm{p}=0,005$ sehingga dapat disimpulkan bahwa terjadi peningkatan pemahaman manajemen waktu pada siswa SMP melalui bimbingan kelompok dengan teknik problem solving. Hasil penelitian ini dapat bermanfaat bagi guru bimbingan dan konseling sebagai bahan pertimbangan dalam meningkatkan pemahaman manajemen waktu siswa melalui layanan bimbingan kelompok dengan teknik problem solving.

Kata kunci: bimbingan kelompok, problem solving, manajemen waktu

\section{Pendahuluan}

Masa remaja memiliki tugas perkembangan yang harus dicapai agar remaja dapat berkembang dengan optimal. Tugas perkembangan tersebut antara lain berkaitan dengan perkembangan etika, nilai, kecerdasan intelektual, emosi, dan spiritual (Santrock, 2007: 20). Pada masa remaja seringkali terjadi masalah kesulitan manajemen waktu karena tidak mempunyai pemahaman mengenai manajemen waktu. Ketidakmampuan dan ketidakpahaman dalam memanajemen waktu dapat menimbulkan dampak buruk bagi siswa yaitu banyak kesempatan yang terbuang sia-sia.
Pemahaman siswa tentang manajemen waktu akan membentuk pribadi yang disiplin. Siswa harus terlatih dalam mengatur dan mengalokasikan waktu setiap hari. Pengaturan waktu yang baik membuat siswa mampu memisahkan kegiatan belajar dan kegiatan pribadi.

Teknik problem solving (teknik pemecahan masalah) merupakan suatu proses yang kreatif dimana individu menilai perubahan-perubahan yang ada pada diri dan lingkungan, membuat pilihan-pilihan baru, keputusan-keputusan, serta penyesuaian yang selaras dengan tujuan-tujuan dan nilai-nilai hidupnya. Teknik problem solving dapat digunakan untuk membantu siswa dalam memberikan pemahaman pentingnya manajemen 


\section{NURHIDAYATI}

waktu. Melalui teknik ini, siswa dituntut untuk lebih kreatif dan kritis untuk mengungkapkan masalah-masalah yang terjadi akibat pemahaman manajemen waktu yang kurang dan kesulitankesulitan yang dialami siswa ketika memanajemen waktu. Selanjutnya siswa menganalisis masalah-masalah dan kesulitankesulitan tersebut untuk menemukan alternatifalternatif solusi yang dapat diterapkan oleh siswa. Pada dasarnya teknik ini mendorong siswa untuk bertanggung jawab dalam menyelesaikan setiap masalah dan kesulitan-kesulitan dalam mengelola waktu secara mandiri sehingga pemahaman manajemen waktu siswa menjadi bertambah karena saling bertukar informasi dan solusi.

Hasil analisis DCM (Daftar Cek Masalah) yang dilakukan pada siswa kelas VII A SMP Muhammadiyah 4 Yogyakarta menunjukkan persentase paling tinggi pada permasalahan kebiasaan belajar siswa dibandingkan dengan beberapa permasalahan yang lain. Perolehan ratarata hasil analisis DCM tersebut sebesar 58\% pada permasalahan kebiasaan belajar. Permasalahan-permasalahan tersebut sebagian besar yaitu, siswa merasa mengantuk saat belajar $(30,30 \%)$, siswa hanya belajar pada malam hari $(18,18 \%)$, siswa tidak memiliki waktu belajar secara teratur $(15,15 \%)$, sering merasa malas belajar $(12,12 \%)$, siswa sulit mengingat pelajaran yang telah dihafal $(9,09 \%)$, siswa belajar saat ada ulangan $(6,06 \%)$, dan tidak dapat menerapkan cara belajar yang baik $(3,03 \% \%)$. Hasil analisis tersebut menunjukkan salah satu permasalahan dalam kebiasaan belajar adalah siswa tidak memiliki pemahaman tentang manajemen waktu sehingga siswa hanya belajar di malam hari, waktunya tidak teratur, dan belajar saat ada ulangan. Akibat yang ditimbulkan dari permasalahan tersebut yaitu siswa mengalami kesulitan mengingat materi yang telah dipelajari. Kondisi tersebut juga menyebabkan siswa tidak mampu menyelesaikan tugas sekolah secara maksimal.

Berdasarkan hasil wawancara pada sembilan siswa kelas VII A SMP Muhammadiyah 4 Yogyakarta pada Senin tanggal 16 November 2016, mendapatkan informasi bahwa siswa masih memiliki minim pemahaman tentang cara memecahkan permasalahan kebiasaan belajar. Keterbatasan pemahaman siswa terhadap permasalahan kebiasaan belajar menyebabkan siswa seringkali mengerjakan tugas secara terburu-buru menjelang batas akhir pengumpulan tugas, ingin menyelesaikan tugas dengan cepat sehingga mengakibatkan tugas tidak dapat terselesaikan secara baik dan tuntas, dan siswa berkecenderungan untuk mengerjakan tugas secara asal-asalan hanya untuk menggugurkan kewajiban mengumpulkan tugas. Siswa juga menuturkan bahwa untuk menyelesaikan tugas sekolah kerap mengerjakan tugas/pekerjaan rumah secara terburu-buru di sekolah pada saat akhir batas waktu pengumpulan. Selain itu, para siswa menceritakan bahwa mereka memiliki pemahaman terbatas mengenai pemanfaatan waktu secara baik sehingga tidak memiliki kebiasaan belajar yang teratur. Berdasarkan permasalahan yang telah dipaparkan maka secara mengerucut dapat disimpulkan bahwa terdapat permasalahan pada siswa dalam kebiasaan belajar yang disebabkan oleh rendahnya pemahaman siswa akan manajemen waktu, khususnya waktu belajar.

Permasalah-masalah di atas membutuhkan penanganan dari guru bimbingan dan konseling. Salah satu teknik dalam bimbingan yang dapat diaplikasikan oleh guru bimbingan dan konseling adalah teknik problem solving. Namun, menurut penuturan tiga guru bimbingan dan konseling di SMP Muhammadiyah 4 Yogyakarta, bahwa teknik problem solving belum pernah diaplikasikan dalam layanan bimbingan dan konseling di sekolah tersebut. (Hasil wawancara Senin tanggal 16 November 2016).

Teknik problem solving yang dikemas melalui bimbingan kelompok dianggap dapat melatih siswa untuk berfikir kritis dalam mengidentifikasi masalah kebiasaan belajar serta mencari solusi dari permasalahan yang dihadapi. Kegiatan ini mengajarkan siswa untuk menanamkan rasa tanggung jawab dalam mencari solusi dari kasus yang sedang dihadapi melalui pembahasan dalam diskusi kelompok. Siswa diharapkan mendapatkan pemahaman baru mengenai manajemen waktu melalui pemberian informasi dalam bentuk contoh kasus. Selain itu, siswa dapat belajar untuk mengungkapkan, menggambarkan, serta mengekspresikan pemahaman dalam mengelola waktu. Siswa yang kurang mengetahui cara mengatur waktu secara baik dapat memperoleh informasi baru tentang manajemen waktu sehingga siswa dalam 


\section{MANAJEMEN WAKTU, BIMBINGAN KELOMPOK, PROBLEM SOLVING}

menjalankan aktivitas baik di sekolah maupun di rumah dapat menerapkan kebiasaan menjadi pribadi-pribadi yang disiplin dan bertanggung jawab.

Penelitian ini bertujuan untuk mengetahui peningkatan pemahaman manajemen waktu pada siswa kelas VII A SMP Muhammadiyah 4 Yogyakarta melalui layanan bimbingan kelompok dengan teknik problem solving. Manajemen waktu belajar memiliki peranan besar dalam keberhasilan belajar siswa. Oleh karena itu, pemahaman manajemen waktu pada siswa, perlu untuk ditingkatkan. Melalui teknik problem solving, siswa dapat belajar untuk berfikir secara kritis dan ilmiah sehingga lebih aktif dalam mengidentifikasi masalah, mengolah, serta merumuskan solusi terbaik dalam memecahkan permasalahan yang berkaitan dengan managemen waktu belajar. Hasil penelitian ini dapat bermanfaat bagi guru bimbingan dan konseling sebagai bahan pertimbangan dalam meningkatkan pemahaman manajemen waktu siswa melalui layanan bimbingan kelompok dengan teknik problem solving.

\section{Kajian Literatur}

\section{Manajemen Waktu}

Manajemen waktu memiliki peranan besar dalam keberhasilan belajar siswa. Siswa yang tidak memiliki pemahaman manajemen waktu ditandai dengan perencanaan yang tidak terorganisasi, tidak jelas, tidak konsisten, tidak ada tujuan, dan kurang disiplin dalam menggunakan waktu. Menanamkan sikap tanggung jawab dan disiplin dalam menyelesaikan tugas sesuai jadwal yang ditentukan, akan menjadikan siswa mampu mencapai target belajar dengan mencapai hasil yang optimal. Menurut Mujiyono, dkk (2009: 5) manajemen waktu adalah perencanaan, pengorganisasian, penggerakan, dan pengawasan produktivitas waktu. Sejalan dengan hal tersebut Purwanto (2008: 6) berpendapat bahwa manajemen waktu adalah proses harian yang digunakan untuk membagi waktu, membuat jadwal, daftar hal-hal yang harus dilakukan, pendelegasian tugas, dan sistem lain yang membantu untuk menggunakan waktu secara efektif.
Permasalahan kesulitan memanajemen waktu sering terjadi pada masa remaja. Siswa Sekolah Menengah Pertama (SMP) merupakan masa transisi antara masa anak-anak dan masa dewasa, pada masa ini remaja sangat rawan oleh pengaruh-pengaruh negatif, namun di samping itu remaja merupakan masa yang baik dan mempunyai potensi-potensi untuk dikembangkan dan diarahkan menuju masa perkembangan yang sehat. Manajemen waktu yang benar diperlukan dalam kehidupan remaja karena secara sosiologis, remaja berada pada keadaan yang rentan terhadap pengaruh-pengaruh eksternal. Masa remaja merupakan masa d imana proses pencarian jati diri sedang dilakukan sehingga pada masa ini remaja mudah sekali terombang-ambing dan masih merasa sulit mengambil keputusan dalam kehidupan secara mandiri. Remaja mudah terpengaruh oleh gaya hidup masyarakat di sekitar dan pada kelompok teman sebaya. Kondisi kejiwaan yang labil mengakibatkan remaja mudah terpengaruh oleh lingkungan.

Manajemen waktu memiliki beberapa aspek yang perlu diketahui oleh setiap siswa. Tiger (1999: 381) mengemukakan aspek-aspek dalam manajemen waktu yaitu: a) penetapan tujuan dan prioritas; b) mekanisme manajemen waktu; c) kontrol terhadap waktu. Penetapan tujuan dan prioritas tersebut ditetapkan berkaitan dengan tugas dan tanggung jawab yang dipikul siswa pada saat itu. Misalnya, dalam suatu minggu di sekolah akan dilakukan ujian, sementara siswa juga mempunyai jadwal rutin les musik, dan mengumpulkan tugas mandiri. Berkaitan dengan tiga kegiatan tersebut siswa harus memilih mana yang lebih penting untuk didahulukan antara mempersiapkan ujian, mengumpulkan tugas mandiri atau les musik. Siswa menetapkan tujuan dari masing-masing kegiatan tersebut. Mengerjakan tugas mandiri dan ujian bagian utama dari tugas perkembangan siswa, dimana tugas mandiri ikut berperan memberikan bobot penilaian yang diberikan guru di luar nilai ujian, sedangkan les musik merupakan kegiatan pengembangan hobi. Oleh karena itu, siswa harus menetapkan tujuan dari ketiga kegiatan tersebut.

Mekanisme dalam manajemen waktu adalah tata cara atau langkah-langkah yang harus dilakukan manajemen waktu dari mulai perencanaan sampai dengan evaluasi. Selanjutnya siswa harus menetapkan jadwal urutan untuk 


\section{NURHIDAYATI}

melaksanakan ketiga kegiatan tersebut. Sesuai dengan tujuan tugas perkembangan siswa, maka hal pertama yang harus dilakukan adalah menyelesaikan tugas mandiri, belajar untuk mempersiapkan ujian, dan kemudian les musik.

Kontrol terhadap waktu dilakukan dengan melakukan pengawasan terhadap aplikasi waktu per kegiatan yang telah di rencanakan di awal. Jadi siswa dituntut untuk melakukan pengawasan terhadap alokasi waktu per kegiatan yang telah direncanakan, ditargetkan di awal, apakah alokasi menetapkan yang di targetkan untuk suatu kegiatan sudah cukup atau belum. Aspek-aspek tersebut diperkuat oleh hasil riset yang dilakukan Jithendra M. Mishra dan Prabhakara Mishra (dalam Rohadi, 2008: 291). Hasil riset tersebut menyimpulkan ada lima bidang utama yang tidak boleh ditinggalkan dalam pengelolaan waktu atau manajemen waktu, yaitu: pertama, kesadaran bahwa sebagian besar waktu yang dihabiskan bersifat kebiasaan; kedua, bahwa penentuan sasaran pribadi sangat penting bagi manajemen yang benar; ketiga, prioritas harus dikategorikan dan dikaji; keempat, bahwa komunikasi yang baik dan benar sangat esensial; kelima, bahwa menangguhkan mungkin merupakan halangan terbesar bagi pengelolaan waktu.

Siswa diharapkan dapat menyusun pedoman mengatur waktu belajar dan konsisten menjalankan waktu yang telah dijadikan pedoman. Pedoman pokok manajemen waktu yang harus dipahami dan diterapkan siswa adalah cara mengelompokkan waktu untuk belajar. Siswa diharapkan dapat merencanakan dan menetapkan waktu belajar setiap hari agar terbiasa dengan jadwal yang telah dibuat sehingga siswa dapat memanfaatkan waktu dengan baik.

Siswa memerlukan alternatif teknik-teknik dalam memanfaatkan waktu untuk belajar. Gie (1995: 179) menyebutkan ada empat teknik dalam memanfaatkan manajemen waktu untuk belajar: a) siswa hendaknya menetapkan mata pelajaran yang akan dipelajarinya setiap hari sekurangkurangnya dua atau empat mata pelajaran setiap hari; b) mengurutkan waktu mempelajari dua atau empat mata pelajaran itu menurut sukar mudahnya yang dikaitkan dengan kapan siswa mencapai waktu terbaik untuk belajar; c) mengatur lamanya periode belajar sebaik-baiknya agar tidak terlampau pendek atau terlalu lama, berapa lama periode waktu belajar sebaiknya ditetapkan oleh individu bersangkutan; d) belajar secara intensif untuk menguasai suatu mata pelajaran. Teknik ini digunakan untuk mempelajari mata pelajaran yang dianggap sukar sehingga perlu teknik khusus untuk mempelajari dan memahami pelajaran tersebut.

Rahardi (2008: 88) menjelaskan beberapa faktor yang menentukan tercapainya proses manajemen waktu siswa antara lain: a) faktor dalam diri yang melakukan kesalahan; b) faktor pandangan hidup (life way); c) faktor lingkungan sekolah. Pemahaman terhadap faktor-faktor yang mempengaruhi memanajemen waktu, dapat dilakukan sebagai upaya untuk meningkatkan kemampuan memanajemen waktu di lingkungan sekolah yang dilaksanakan dalam suatu kegiatan belajar dengan layanan bimbingan kelompok.

Pemahaman manajemen waktu perlu diukur agar dapat dievaluasi atau diperbaiki. Menurut Hasan (1991: 78), pemahaman diukur melalui tiga aspek pemahaman yaitu: a) pemahaman sebagai bentuk penerimaan; b) respon; dan c) penilaian terhadap suatu objek. Pengukuran pemahaman manajemen waktu melalui bimbingan kelompok dilakukan dengan menggunakan tiga cara yaitu dengan melihat penerimaan siswa ketika mendapat layanan tentang manajemen waktu, bagaimana respon siswa dalam menanggapi, dan memunculkan ide-ide baru ketika pelaksanaan kegiatan, serta bagaimana penilaian siswa dalam menyelesaikan suatu permasalahan terkait manajemen waktu secara logis.

Upaya meningkatkan pemahaman manajemen waktu dapat dilakukan dengan cara pemberian informasi atau pengetahuan tentang manajemen waktu agar siswa memiliki pengetahuan manajemen waktu, cara meningkatkan manajemen waktu, keterampilan cara mengatur waktu, teknik menyusun waktu, serta faktorfaktor yang mempengaruhi manajemen waktu. Hal ini menjadi penting agar siswa mampu meningkatkan harga diri dan meningkatkan sikap asertif sehingga siswa dapat menolak dan menghindari hal-hal yang bisa menggangu tercapainya manajemen waktu yang telah ditetapkan.

\section{Layanan Bimbingan Kelompok}

Layanan bimbingan kelompok merupakan layanan yang diberikan dalam suasana kelompok untuk memberikan informasi berdasarkan 


\section{MANAJEMEN WAKTU, BIMBINGAN KELOMPOK, PROBLEM SOLVING}

kepentingan kelompok. Menurut Sukardi (2008: 64) bimbingan kelompok adalah layanan bimbingan kelompok adalah layanan bimbingan yang memungkinkan sejumlah peserta didik secara bersama-sama memperoleh berbagai bahan dari sumber tertentu (terutama daripembimbing/konselor) yang berguna untuk menunjang kehidupannya sehari-hari sebagai pelajar, anggota keluarga dan masyarakat serta untuk pertimbangan dalam pengambilan keputusan. Menurut Romlah (2006: 3) pengertian bimbingan kelompok adalah proses pemberian bantuan yang diberikan pada individu dalam situasi kelompok. Bimbingan kelompok ditunjukkan untuk mencegah timbulnya masalah pada siswa dan mengembangkan potensi siswa. Berdasarkan pendapat ahli dan dikaitkan dengan mnajemen waktu, maka dapat disimpulkan bahwa bimbingan kelompok adalah layanan bimbingan yang memungkinkan sejumlah siswa secara bersama-sama memperoleh berbagai pemahaman mengenai manajemen waktu sehingga mampu mengambil keputusan untuk mengatasi kesulitan manajemen waktu dengan strategi yang tepat dan efisien untuk meningkatkan hasil belajar.

Komponen layanan bimbingan kelompok merupakan bagian-bagian dalam memberikan layanan bimbingan kelompok secara keseluruhan sebagai satu kesatuan proses layanan bimbingan kelompok. Menurut Prayitno (1995: 27) ada tiga komponen penting dalam kelompok yaitu: a) suasana kelompok; b) anggota kelompok, peranan kelompok tidak terwujud tanpa keikutsertaan aktif para anggota kelompok dan bahkan lebih dari itu, dalam batasan-batasan tertentu suatu kelompok dapat melakukan kegiatan tanpa kehidupan pimpinan kelompok; c) pemimpin kelompok adalah orang yang mampu menciptakan suasana sehingga para anggota kelompok dapat belajar bagaimana cara mengatasi masalah-masalah mereka sendiri. Peranan pemimpin kelompok dalam layanan bimbingan kelompok adalah memberi bantuan, pengarahan ataupun campur tangan langsung terhadap kegiatan kelompok, dan memusatkan perhatian pada suasana perasaan yang berkembang dalam kelompok itu.

Menurut Romlah (2006: 87) ada beberapa teknik yang bisa digunakan dalam pelaksanaan bimbingan kelompok, yaitu: a) teknik pemberian informasi (expository techniques); b) diskusi kelompok; c) teknik pemecahan masalah (problem solving techniques); d) permainan peran (roleplaying); e) permainan simulasi (simulation game); f) karyawisata (field trip); dan g) teknik pencipta suasana kekeluargaan (homeroom). Layanan bimbingan kelompok dengan teknik problem solving dilakukan dengan cara melakukan diskusi untuk membuat penilaian dan merumuskan keputusan untuk menyelesaikan suatu permasalahan. Pada penelitian ini, permasalahan yang dimaksudkan terkait dengan manajemen waktu sehingga siswa membuat penilaian terhadap kesulitan memanajemen waktu berdasarkan penyebabnya (baik faktor dari dalam diri maupun dari lingkungan) dan secara bersama-sama siswa merumuskan keputusankeputusan untuk menyelesaikan masalah dengan memperbaiki pandangan hidup dan memotivasi siswa untuk memanajemen waktu.

Tahap-tahap bimbingan kelompok merupakan bagian-bagian secara berurutan yang dilakukan dalam layanan bimbingan kelompok kepada masing-masing siswa untuk mengatasi permasalahan yang dihadapi secara berkelompok. Menurut Hartinah (2009: 131) ada empat tahap dalam pelaksanaan bimbingan kelompok yaitu: a) tahap pembentukan (awal), tahap ini tahap pengenalan dan keterlibatan anggota ke dalam kelompok dengan tujuan agar anggota kelompok memahami maksud bimbingan kelompok untuk meningkatkan pemahaman mengenai manajemen waktu; b) tahap peralihan, tahap ini adalah tahap transisi dari pembentukan ke tahap kegiatan, menjelaskan kegiatan apa yang harus dilaksanakan pemimpin kelompok untuk menegaskan jenis kegiatan bimbingan kelompok yaitu tugas dan beban, sehingga tidak akan muncul keraguan atau belum siap dalam melaksanakan kegiatan dan manfaat yang diperoleh setiap anggota kelompok; c) tahap pelaksanaan kegiatan yaitu kegiatan yang dilakukan pada tahap ini untuk topik tugas adalah pemimpin kelompok mengemukakan topik untuk dibahas oleh kelompok, dan d) tahap pengakhiran, pada tahap ini terdapat dua kegiatan yaitu penilaian (evaluasi) dan tindak lanjut (follow up). 


\section{NURHIDAYATI}

Teknik Problem Solving untuk Meningkatkan Pemahaman Manajemen Waktu

Teknik problem solving merupakan salah satu teknik dalam pelayanan bimbingan dan konseling. Penekanan teknik problem solving terletak pada masalah dan pemecahan masalah. Romlah (2006: 93) mengemukakan teknik problem solving (problem solving tecniques) adalah suatu proses yang kreatif dimana individu-individu menilai perubahan-perubahan yang ada pada dirinya dan lingkungannya dan membuat pilihan-pilihan baru, keputusan-keputusan atau penyesuaian yang selaras dengan tujuan-tujuan dan nilai hidupnya. Problem solving merupakan suatu pemahaman yang meliputi kemampuan untuk mencari informasi, menganalisa dan mengidentifikasi masalah dengan tujuan untuk menghasilkan alternatif sehingga dapat mengambil suatu tindakan keputusan untuk mencapai sasaran.

Terdapat beberapa faktor yang dapat mempengaruhi kemampuan siswa dalam melakukan problem solving. Menurut Rakhmat (2008: 74) problem solving dipengaruhi oleh faktor-faktor seperti: a.) motivasi, motivasi yang salah cenderung akan mengalihkan perhatian ke hal yang lain. Motivasi yang tinggi akan membatasi fleksibilitas, artinya bahwa motivasi yang tinggi akan tetap konsisten terhadap segala hal, dan b) kepercayaan, asumsi yang salah dapat menyesatkan siswa. Apabila siswa percaya bahwa kebahagiaan dapat diperoleh dengan kekayaan material, maka akan mengalami kesulitan ketika memecahkan penderitaan batinnya.

Berdasarkan penjelasan tersebut peningkatan pemahaman manajemen waktu melalui bimbingan kelompok dengan teknik problem solving dilakukan dengan meningkatkan motivasi siswa untuk mengatasi hal-hal yang dapat menyebabkaan kesulitan manajemen waktu, dengan menanamkan kepercayaan dan nilai-nilai untuk mengatasi kesulitan memanajemen waktu. Djamarah dan Zain (2004: 104) menjelaskan kelebihan dari teknik problem solving: a) teknik ini membuat pendidikan di sekolah menjadi relevan dengan kehidupan; b) dapat membiasakan pada siswa untuk menghadapi permasalahan di dalam kehidupan; c) mengembangkan proses berfikir siswa secara kreatif dan menyeluruh; d) melatih siswa untuk mengidentifikasi dan melakukan penyelidikan; e) memberikan kesempatan kepada siswa untuk mengaplikasikan pengetahuan yang mereka miliki dalam dunia nyata. Roestiyah (2001: 95) menjelaskan kelemahan teknik problem solving: a) manakala siswa tidak memiliki minat dan tidak memiliki kepercayaan bahwa masalah yang dipelajari sulit dipecahkan, maka siswa akan merasa enggan untuk mencoba; b) mengubah kebiasaan belajar siswa dari mendengarkan dan menerima informasi dari guru menjadi belajar dengan banyak berfikir memecahkan permasalahan sendiri atau kelompok kadang memerlukan berbagai sumber belajar merupakan kesulitan tersendiri bagi siswa; c) proses belajar mengajar dengan menggunakan metode ini sering memerlukan waktu yang cukup banyak.

Berdasarkan kelebihan dan kekurangan teknik problem solving, tentu banyak kelebihan dibanding dengan kekurangan. Kelebihan dari teknik ini yaitu siswa dituntut untuk berfikir secara kritis dan ilmiah sehingga siswa lebih aktif dalam mengidentifikasi masalah, mengolah, serta merumuskan solusi terbaik dalam memecahkan masalah memanajemen waktu. Melihat kelebihankelebihan yang ada pada teknik problem solving, maka teknik ini dipandang cocok dan tepat digunakan dalam meningkatkan pemahaman manajemen waktu siswa. Teknik problem solving juga juga dapat meningkatkan kemampuan siswa dalam berfikir secara kritis dan mandiri agar mampu menyelesaikan permasalahan dalam manajemen waktu.

Menurut Rinaldi (2011: 110) karakteristik teknik problem solving: a) teknik problem solving merupakan serangkaian aktivitas bimbingan; b) aktivitas bimbingan diarahkan untuk menyelesaikan masalah; c) pemecahan masalah menggunakan pendekatan berfikir secara kritis dan ilmiah. Teknik problem solving merupakan teknik untuk memberikan informasi kepada siswa melalui proses memecahkan masalah yang berkaitan dengan manajemen waktu sehingga berbagai informasi tentang manajemen waktu dapat tersampaikan dengan efektif. Siswa dituntut untuk menyelesaikan masalahmasalah manajemen waktu yang dialami diri sendiri atau siswa lain.

Pemecahan masalah mengutamakan siswa untuk berfikir kritis dalam mengidentifikasi masalah, merumuskan sebab-sebab terjadinya 
masalah, mencari alternatif pemecahan masalah, serta mengadakan penilaian terhadap hasil yang akan dicapai. Guru bimbingan dan konseling hanya bertugas mengarahkan siswa sehingga siswa dituntut aktif dan berfikir ilmiah dan kritis. Keaktifan siswa akan mempermudah dan mempercepat dalam memahami manajemen waktu karena siswa berfikir sendiri melalui kasus yang diselesaikan yaitu masalah tentang manajemen waktu. Dengan demikian, teknik problem solving dianggap cocok sebagai cara untuk meningkatkan pemahaman manajemen waktu siswa karena siswa dibebaskan untuk mengeluarkan pendapat sesuai dengan pemahaman yang dimiliki dalam memecahkan masalah yang sedang dihadapi terutama masalah dalam manajemen waktu.

\section{Metode Penelitian}

Penelitian ini menggunakan pendekatan penelitian tindakan kelas (classroom action research) dengan jenis cross sectional. Subjek penelitian sebanyak sepuluh siswa kelas VII A SMP Muhammadiyah 4 Yogyakarta, yang diambil dengan teknik purposive sampling. Instrumen pengumpulan data yang digunakan berupa angket pemahaman manajemen waktu siswa. Instrumen pengumpulan data yang digunakan berupa angket pemahaman manajemen waktu. Teknik analisis data untuk menguji keefektifan bimbingan kelompok dengan teknik problem solving dalam meningkatkan pemahaman manajemen waktu siswa SMP menggunakan uji wilcoxon.

\section{Hasil Penelitian dan Pembahasan}

Peningkatan pemahaman manajemen waktu pada siswa dapat tercapai melalui layanan bimbingan kelompok dengan teknik problem solving. Skor pre test dan post test dianalisis menggunakan uji wilcoxon untuk melihat peningkatan pemahaman manajemen waktu pada siswa melalui teknik problem solving. Hasil analisis data menunjukkan bahwa terjadi peningkatan pemahaman manajemen waktu siswa SMP melalui layanan bimbingan kelompok dengan teknik problem solving. Peningkatan tersebut dapat terlihat dari perbedaan rerata skor pretest dan posttest. Rerata skor pretest sebesar
55,30 mengalami kenaikan pada rerata skor posttest sebesar 78,60. Hasil peningkatan tersebut dapat dilihat pada Tabel 1 .

Tabel 1

Deskripsi Data Variabel Pemahaman Manajemen Waktu Setiap Siswa

\begin{tabular}{llccc}
\hline No & Subjek & $\begin{array}{c}\text { Series 1 } \\
\text { Pre test }\end{array}$ & $\begin{array}{c}\text { Series 2 } \\
\text { Post test }\end{array}$ & $\begin{array}{c}\text { Series 3 } \\
\text { Gain } \\
\text { score }\end{array}$ \\
\hline 1 & ASP & 42 & 82 & 40 \\
2 & NFP & 44 & 72 & 28 \\
3 & ANA & 46 & 70 & 24 \\
4 & DNR & 50 & 73 & 23 \\
5 & SA & 54 & 74 & 20 \\
6 & TQ & 59 & 73 & 14 \\
7 & FAS & 61 & 83 & 22 \\
8 & PW & 64 & 83 & 19 \\
9 & FSR & 65 & 89 & 24 \\
10 & HPO & 68 & 87 & 19 \\
& Jumlah & 553 & 786 & 233 \\
& Mean & 55,30 & 78,60 & 23,30 \\
& Median & 55,50 & 78,00 & 22,50 \\
\hline
\end{tabular}

Hasil analisis data pada pretest menunjukkan bahwa lima siswa (50\%) mempunyai pemahaman manajeman waktu dalam kategori kurang dan sisanya sejumlah 5 siswa (50\%) mempunyai pemahaman tentang manajemen waktu dalam kategori cukup. Hal ini menunjukkan sebagian besar subjek penelitian belum mengetahui dengan benar hal-hal dalam memanajemen waktu yang meliputi pemahaman tentang penetapan tujuan dan prioritas, pemahaman tentang mengatur dan mengelola waktu, dan membuat kontrol terhadap jadwal kegiatan sehingga belum mampu menyediakan waktu untuk kegiatan belajar.

Hasil analisis data pada skor pottest menunjukkan jumlah siswa yang memiliki pemahaman tentang manajeman waktu dalam kategori baik sebanyak delapan siswa (80\%) dan sisanya mempunyai pemahaman tentang manajemen waktu dalam kategori cukup sebanyak 2 siswa (20\%). Hal ini menunjukkan sebagian besar subjek penelitian cukup mengetahui hal-hal dalam memanajemen waktu yang meliputi pemahaman tentang penentapan tujuan dan prioritas, pemahaman tentang mengatur dan mengelola waktu, dan membuat 


\section{NURHIDAYATI}

kontrol terhadap jadwal kegiatan sehingga belum mampu menyediakan waktu untuk kegiatan belajar. Perbandingan skor pretest dan posttest dapat ditunjukkan pada Gambar 1.

\section{Perbandingan Skor Pretest dan Posttest}

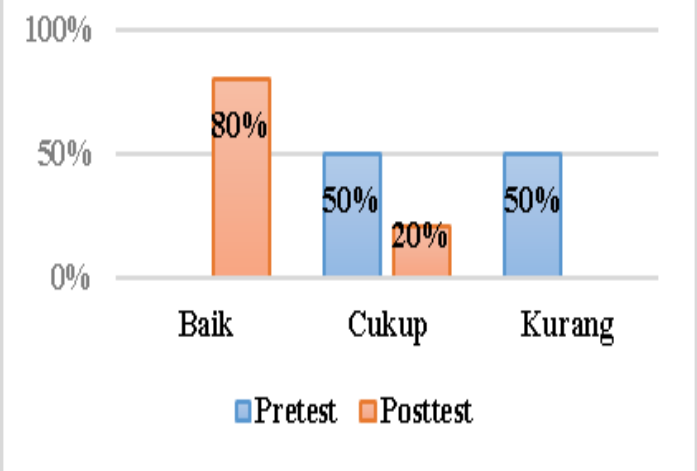

\section{Gambar 1}

Perbandingan Skor Pretest dan Posttest

Data hasil observasi menjadi data pendukung untuk melihat peningkatan pemahaman manajemen waktu siswa melalui layanan bimbingan kelompok dengan teknik problem solving. Berdasarkan hasil observasi pada siklus I dan II dapat diketahui respon yang diberikan siswa saat pelaksanaan problem solving berjalan dengan cukup lancar dan cukup kondusif tetapi saat pelaksanaan problem solving beberapa siswa kurang mampu menyampaikan pendapatnya dalam diskusi pelaksanaan Problem solving yaitu ANA, FAS, PW, FSR dan HPO. Hasil observasi siklus I menunjukkan siswa cukup fokus memperhatikan informasi yang disampaikan peneliti atau pemimpin kelompok, cukup aktif bertanya, cukup percaya diri, dan berani tampil berargumentasi atau mengemukakan pendapat, cukup terampil dalam menanggapi pendapat anggota lain, berbicara cukup terarah, tidak terbata-bata, tidak ragu, bahasa yang digunakan cukup dapat dipahami, sopan, tidak kasar, ckup dalam menghormatiantar anggota kelompok, cukup terbuka dengan anggota yang lain, cukup mampu berinteraksi dengan baik dengan anggot kelompok yang lain, tertib dalm mengikuti kegiatan dan cukup memberikan reward berupa pujian ekspresi dan tepukan tangan.

Pada siklus II respon siswa dan situasi kelompok sudah berada pada kategori baik. Siswa fokus memperhatikan informasi yang disampaikan peneliti atau pemimpin kelompok, aktif bertanya, aktif dalam mencatat hal-hal yang penting, percaya diri dan berani berargumentasi atau mengemukakan pendapat, terampil dalam menanggapi pendapat anggota lain, bicaranya terarah, tidak terbata-bata, tidak ragu, bahasa yang digunakan mudah dipahami, sopan santun, tidak berbicara kasar, saling menghormati pendapat antar anggota, saling terbuka dengan anggota yang lain, mampu berinteraksi dengan baik dengan anggota kelompok, tertib, serta memberikan reward berupa pujian ekspresi dan tepukan tangan dan lainnya. Berdasarkan hasil penelitian ini, peneliti menyimpulkan bahwa layanan bimbingan kelompok dengan teknik problem solving dapat meningkatkan pemahaman tentang manajemen waktu.

Pengujian hipotesis menggunakan uji wilcoxon dengan bantuan program SPSS diperoleh nilai $p=0,005(<0,05)$ maka hipotesis alternatif (Ha) yang diajukan "ada peningkatan pemahaman manajemen waktu melalui teknik problem solving pada siswa kelas VII A SMP Muhammadiyah 4 Yogyakarta" diterima sehingga teruji kebenarannya. Hasil pengujian tersebut dapat disimpulkan bahwa ada perbedaan yang signifikan antara pemahaman manajemen waktu sebelum dan setelah diberi teknik problem solving.

\section{Simpulan}

Berdasarkan hasil penelitian dapat disimpulkan bahwa layanan bimbingan kelompok dengan teknik problem solving dapat meningkatkan pemahaman manajemen waktu pada siswa kelas VII A SMP Muhammadiyah 4 Yogyakarta. Hasil penelitian ini dapat bermanfaat bagi guru bimbingan dan konseling sebagai bahan pertimbangan dalam meningkatkan pemahaman manajemen waktu siswa melalui layanan bimbingan kelompok dengan teknik problem solving.

\section{Referensi}

Atkhinson, E. Philip. (1983). Manajemen Waktu yang Efektif. Jakarta: Bina Rupa

(1983). Manajemen

Waktu yang Kreatif. Bandung: Remaja

Rosda Karya. 


\section{MANAJEMEN WAKTU, BIMBINGAN KELOMPOK, PROBLEM SOLVING}

Depdiknas. (2007). Penataan Pendidikan Profesional Konselor dan Layanan Bimbingan dan Konseling dalam Jalur Pendidikan Formal. Jakarta.

Geldrad, Katryn dan David Geldrad. (2011). Konseling Remaja Pendekatan Proaktif untuk Anak Muda. Yogyakarta: Pustaka Pelajar.

Gie, The Liang. (1995). Strategi Hidup Sukses. Yogyakarta: Liberty.

Gunarso, Singgih. (2000). Psikologi Perkembangan. Jakarta: BPK Gunung Mulia.

Hamid, Hasan. (1991). Evaluasi Belajar. Jakarta: Depdikbud Dirjendikti.

Hartinah, Siti. (2010). Perkembangan Peserta Didik. Bandung: Refika Aditama.

Haryati, Mimin. (2007). Model dan Teknik Penilaian pada Tingkat Pendidikan. Jakarta: GP Press.

Haynes, Marion E. (2010). Manajemen Waktu. Jakarta: PT Indeks.

Mujiono, dkk. (2009). Modul Pengembangan Diri melalui Layanan Bimbingan dan Konseling SMK. Yogyakrta: Paramitha Publishing.

Prayitno. (1995). Layanan Bimbingan dan Konseling Kelompok (Dasar dan Profil). Jakarta: Ghalia Indonesia.

Purwanto, Sigit. (2008). Pocket Mentor Manajemen Waktu. Jakarta: Esensi Erlangga Group.

Rohadi. (2008). Pengaruh Manajemen Waktu dan Motivasi Mengajar terhadap Kompetensi Profesional Guru di Sekolah Menengah Atas Kota Pekalongan. Tesis. Semarang: Program Studi Manajemen Pendidikan Pogram Pascasarjana Universitas Negeri Semarang.
Romlah, Tatiek. (2006). Teori dan Praktek Bimbingan Kelompok. Malang: Universitas Negeri Malang.

Slamet. (2003). Belajar dan Faktor-Faktor yang Mempengaruhinya. Jakarta: Rineka Cipta.

Sugiyono. (2010). Metode Penelitian Pendidikan Pendekatan Kuantitatif, Kualitatif, dan R\&D. Bandung: Alfabeta.

Suharsimi, Arikunto. (2006). Prosedur penelitian. Jakarta: Rineka Cipta.

$$
\text { (2010). Prosedur }
$$

Penelitian Suatu Pendekatan Praktik. Jakarta: Rineka Cipta. (2010). Penelitian Tindakan Kelas. Jakarta: Bumi Aksara.

(2011). Dasar-Dasar Evaluasi Pendidikan. Jakarta: Bumi Aksara.

Sukardi, Dewa Ketut. (2008). Pengantar Pelaksanaan Program Bimbingan dan Konseling di Sekolah. Jakarta: Rineka Cipta.

Tiger, Therese Hoff. (1999). Time Management: Test of Proses Model. Jurnal of appliet psychologi, 79(3): 381-391.

Winkel, W.S dan Hastuti, Sri. (2004). Psikologi Pengajaran. Yogyakarta: Media Abadi.

Winkel, W.S dan Hastuti, Sri. (2004). Bimbingan dan Konseling di Institusi Pendidikan. Yogyakarta: Media Abadi.

Yusuf, Syamsu. (2009). Program Bimbingan dan Konseling di Sekolah. Bandung: Rizqi.

Yusuf, Syamsu \& Nurihsan, A. Juntika. (2009). Landasan Bimbingan dan Konseling. Bandung: Remaja Rosdakarya.

Yusuf L. N. (2011). Psikologi Anak dan Remaja. Bandung: Remaja Rosdakarya. 